Bond University

Research Repository

\title{
Psychological Perceptions Matter: Developing the Reactions to the Physical Work Environment Scale
}

\author{
Sander, Elizabeth J
}

Published in:

Building and Environment

DOI:

10.1016/j.buildenv.2018.11.020

Licence:

CC BY-NC-ND

Link to output in Bond University research repository.

Recommended citation(APA):

Sander, E. J. (2019). Psychological Perceptions Matter: Developing the Reactions to the Physical Work

Environment Scale. Building and Environment, 148, 338-347. https://doi.org/10.1016/j.buildenv.2018.11.020

\section{General rights}

Copyright and moral rights for the publications made accessible in the public portal are retained by the authors and/or other copyright owners and it is a condition of accessing publications that users recognise and abide by the legal requirements associated with these rights.

For more information, or if you believe that this document breaches copyright, please contact the Bond University research repository coordinator. 
Psychological Perceptions Matter: Developing the Reactions to the Physical Work Environment Scale

Elizabeth J. Sander (Corresponding Author)

Bond Business School, Bond University

14 University Drive, Robina, Qld, Australia, 4226.

E: lsander@bond.edu.au P: +61755953334

Arran Caza

Asper School of Business, University of Manitoba, Canada.

Peter J. Jordan

Griffith Business School, Griffith University, Australia 


\section{Perceptions Matter: The Reactions to the Physical Work}

\section{Environment Scale}

There is clear research evidence that physical work environments (i.e. material spaces and objects) influence employee performance and wellbeing. As a result, these environments have received significant attention from both practitioners and researchers. However, the outcomes of these applied initiatives and research studies are difficult to compare as they often lack a common framework or are focussed exclusively on the objective qualities of the workspace (e.g. lighting, acoustics) without considering the human element. In this article, we outline a series of studies conducted to examine employees' psychological reactions to the physical work environment. A three-part framework for these reactions is proposed and a supporting measure developed and validated. This new measure, the Reactions to the Physical Work Environment Scale (RPWES), assesses key cognitive, emotional, and relational responses of employees to their physical work environment. The RPWES provides the foundation for a broader understanding of the impact of the physical work environment on employees. Implications for theory and practice are discussed.

Keywords: physical environment; workspace design, psychological reactions, collaboration, empowerment 


\section{Introduction}

The space in which employees work is no longer viewed as an incidental context; rather, organizations are exploring ways of using the work environment to support employee performance and well-being (Davis, Leach \& Clegg, 2011). The importance of employees' reactions to the physical environment has been recognized since at least the time of the Hawthorne experiments (Roethlisberger \& Dickson, 1939), but the practical and theoretical attention paid to the environment has increased greatly in recent years (Davis et al., 2011; Elsbach \& Pratt, 2007). This increased attention highlights the need for better theory and new frameworks to understand the effects of the physical work environment on employees, since the nature of work and the environments in which it is conducted have altered dramatically (Kim, Candido, Thomas \& de Dear, 2016; Oldham \& Hackman, 2010). For example, job design is now viewed as "encapsulating the processes and outcomes of how work is structured, organized, experienced, and enacted” (Grant, Fried \& Juillerat, 2011, p. 418), bringing the role of the physical work environment sharply into focus.

As exemplified by Google Inc.’s \$1 billion UK headquarters (Goldhill, 2013), physical workspace is the second largest expense for most organizations (McCoy, 2005) and can influence productivity by as much as 20\% (Leaman \& Bordass, 1999). Accordingly, many organizations are experimenting with workplace design (Hartog, Weijs-Peree \& Appel-Meulenbroek, 2017; Morrow, McElroy \& Scheibe 2012; Spinuzzi, 2012) and exploring ways of using the work environment to support employee performance (Davis et al., 2011; Heerwagen, Kampschroer, Powell \& Loftness, 2004), as well as pursue economic savings (Kim et al., 2016). For example, some organizations are designing their workplaces to resemble the layout of cities, with major avenues, a town square, and a variety of zones to motivate employees to move 
around the building and share information (Zax, 2013). Still other organizations have attempted to make the workplace an enjoyable location by including gaming spaces and relaxation areas (Baldry \& Hallier, 2009). Organizations are also realizing the need to balance collaboration spaces with quiet or private areas that allow employees to focus and concentrate (Ferro, 2015). Both privacy and interpersonal communication have been examined as critical issues for organizations to address in designing workplaces (Parkinson, Reid, McKerrow \& Wright, 2017), since some modern workplace designs have been linked to increases in sickness absence (Pejtersen, Feveile, Christensen \& Burr, 2011), deterioration in perceived health (Bergstrom, Miller \& Horneij, 2015), and reduced job satisfaction (Kim \& de Dear, 2013).

Despite a significant investment of time and money in workplace design, only one in four employees report working in an optimal environment, and common initiatives such as open plan offices have resulted in more than half of employees reporting feeling disturbed by others when trying to focus (Gensler, 2013). Efforts to increase interaction and collaboration may result in increased distraction, reducing individuals’ ability to focus at work (Bergstrom et al., 2015; Herbig, Schneider \& Nowak, 2016; Kim \& de Dear, 2013). Mixed results of this sort reflect the fact that there is no organizing framework for understanding employees' responses to their physical work environment. Too often, applied efforts and research studies adopt unique and potentially incompatible approaches, preventing the development of a cumulative body of knowledge (Elsbach \& Pratt, 2007). Therefore, the aim of our overall study is to advance future research on the physical work environment by developing a theory-based conceptualization and measure of employee reactions to the work environment. 
We present four studies that develop and validate a measure of employee psychological reactions to the physical work environment. Using a psychological approach (i.e. examinng how employees perceive the physical environment) allows the measure to be applied across a variety of environments. The framework and the measure can serve as the foundation for an integrative understanding how individuals react to physical work environments.

\section{Physical Work Environment}

The physical work environment encompasses the nature and arrangement of all the material objects and stimuli that people encounter in their work, including elements such as building design, room size and shape, furnishings, and equipment, as well as ambient conditions like sound, lighting or air quality (Davis, 1984; Davis et al., 2011; Hedge, 1982; Kim \& de Dear, 2012; Newsham, Brand, Donnelly, Veitch, Aries \& Charles, 2009; Sundstrom, Bell, Busby \& Asmus, 1996). The physical work environment is a central part of organizational life, one that influences beliefs about oneself, coworkers, and the organization (Bitner, 1992). Indeed, even subtle environmental cues influence self-concept and behaviour (Alter, 2013; Caza, Tiedens \& Lee, 2011). For example, Knight and Baer (2014) found that the use of stand-up desks, rather than traditional seated ones, led to better information elaboration, increased arousal, decreased idea territoriality, and ultimately improved team performance (also see Aries, Veitch \& Newsham, 2010; Zhong \& House, 2012).

Because no general framework exists for comprehensively describing employees' reactions (e.g. judgements, emotions, cognitive functioning) to their work environment, most research has focused on isolated aspects of the environment, such as privacy, lighting, or noise (for reviews, see Baron, 1994; Oldham, Cummings \& Zhou, 1995; Sundstrom \& Sundstrom, 1986). Moreover, studies have focussed on the 
relationships among environmental variables and outcomes without an underpinning theory to explain why or how effects occur (Davis et al., 2011; Haynes, 2008; Yanow, 1998). The studies which do draw on theory have used a variety of different models and frameworks (Ashkanasy, Ayoko, \& Jehn, 2014). As a result, reviewers consistently note that current empirical findings are inconsistent, sometimes contradictory, and insufficient to guide practice (Elsbach \& Pratt, 2007; Morgeson , Dierdorff, \& Hmurovic, 2010). In sum, empirical research has demonstrated the importance of discrete aspects of the physical work environment (e.g. furnishings or workspace layout), but without a comprehensive understanding of the different ways in which employees think about and respond to their environment, it is difficult to make a reliable connection between changes in the environment and changes in employee behavior.

\section{Reactions to the Physical Work Environment}

We propose that developing a consistent and generalizable theoretical framework which examines the dimensions of employees' reactions to work environments will enhance our understanding of this phenomenon. Organizational scholars already know how to conceptualize and measure employee perceptions of task and relational characteristics of jobs (e.g. Grant, 2008; Hackman \& Oldham, 1980; Morgeson \& Humphrey, 2006), but we do not have a systematic way to conceptualize and measure employee perceptions of the physical work environment. Our understanding of the dimensions of employee reactions to task and relational job charteristics has allowed the development of a large body of research on the performance and well-being implications of these characteristics (e.g. Bakker \& Demerouti, 2017; Fried \& Ferris, 1987). The lack of such a framework for understanding employee reactions to the physical environment has inhibited the 
development of knowledge about how the physical environment may predict similarly important outcomes in terms of work attitudes or work performance.

We suggest that to be useful, an approach to conceptualizing employee reactions to work environments must be broader than specific reactions to the nearly infinite number of environmental aspects which may vary (color, furnishings, density, lighting, greenery, art, acoustics, etc.). Instead, we identify a more generic suite of employee reactions focussing on the employees' thoughts and perceptions to provide a unifying link between the vast array of environmental features that one might study and employee outcomes. Whether it is an ergonomic feature (e.g. desks, chairs), a physical feature (e.g. plants, layout) or an ambient feature (e.g. lighting, air quality), any organizational or individual outcome linked to that environmental feature depends on how employees perceive, evaluate and respond to it. As such, employee reactions are the linchpin in understanding the behavioral effect of any environmental feature.

Moreover, focusing on employee reactions acknowledges the role of individual differences in work behavior and work outcomes. For example, while some employees may prefer open plan offices, others may prefer isolated spaces. Likewise, some may prefer natural environmental features, while others prefer an industrial ambiance. To understand the effects of a work environment, one must begin with individual reactions, rather than focusing solely on objective aspects of that work environment.

Integrating and extending previous approaches, we focus on the wellestablished psychological framework of cognitive, affective, and relational factors which influence employees at work (Grant \& Parker, 2009). Each of these factors is known to have important implications for employee outcomes (Andrade \& Devlin, 2014; Morgeson \& Humphrey, 2006). These three types of reactions provide a straightforward means of studying employee responses to the environment, and one 
which incorporates the elements that previous research on the physical environment has shown to be important (e.g. Knight \& Baer, 2014; McCoy \& Evans, 2002; Zhong \& House, 2012).

3.1 Cognitive Reactions. Cognition is the processes by which we acquire understanding and knowledge through our thoughts, experiences and senses (Wickens \& Hollands, 2000). Most work tasks require a variety of different cognitive functions (Liebl, Haller, Jödicke, Baumgartner, Schlittmeier \& Hellbrück, 2012), including attending, perceiving, thinking, remembering, and decision-making (Wickens \& Hollands, 2000). For example, modern knowledge work requires employees to attend to specific tasks by gathering, analysing and making decisions using multiple sources of information (Alvesson, 2001). The design and structure of the physical work environment plays a role in supporting cognitive functions (Peponis et al., 2007). When any of these cognitive processes are interrupted, inefficiency and mistakes increase (Liebl et al., 2012). The ability to concentrate and direct attention shapes judgment and behavior (Bazerman \& Chugh, 2006; Dane, 2013), influencing a range of outcomes, including task performance and decision making (Dane, 2011; Hoffman \& Ocasio, 2001; Kilduff, Elfenbein \& Staw, 2010; Marcel, Barr \& Duhaime, 2011). As a result, being able to engage freely in required cognitive activities, to focus on a task without interruption or distraction, is an essential foundation for effective work (Liebl et al., 2012; Wickens \& Hollands, 2000). Moreover, recent data suggest that requirements for concentration and focus at work are increasing (Gensler, 2013; Seddigh, Berntson, Danielsson \& Westerlund, 2014).

In developing a framework to understand employees' cognitive reactions to work environments, we propose the dimension of Focus, or the ability to concentrate on relevant tasks. Focus is the most fundamental cognitive reaction that can be 
influenced by the physical environment, and there is no doubt that physical work environments can greatly enhance or detract from an employee's focus (Banbury \& Berry, 2005; Lee \& Brand, 2005; Veitch \& Gifford, 1996). For example, noise distraction has been found to be among the most significant negative features of open plan work environments, compromising the ability of employees to sustain focus and concentrate on their work (Hongisto, Varjo, Leppamaki, Oliva \& Hyona, 2016; Kim \& de Dear, 2013; Reinten, Braat-Eggen, Hornikx, Kort \& Kohlrausch, 2017). Veitch (2018) suggests that the design and layout of the physical work environment may increase demands on employees through attributes such as high density or low privacy, both of which increase distractions. When it is effortful to focus due to environmental distractions, resources are depleted (Bakker \& Demerouti, 2007; Veitch, 2018) and as such difficulty in focussing is likely to increase stress and strain, undermine performance, and increase errors. However, it is possible that other aspects of workplace design such as views of nature or access to daylight may replenish resources even in the presence of distractors (Veitch, 2018). Employee perceptions of their ability to focus on their work is likely to be an important cognitive dimension of employee responses to their physical work environment.

3.2 Affective Reactions. Affect is an encompassing construct that incorporates both mood and emotion. There is extensive evidence about the importance of affect at work, and its subsequent influence on work attitudes and behaviors (Elfenbein, 2007). For example, positive affect has been shown to increase cognitive flexibility (Isen, 1987), creative problem solving (Isen, Daubman, \& Nowicki, 1987), organizational commitment and helping behaviors (Fisher, 2002), and performance (Lyubomirsky, King, \& Diener, 2005). 
Affective reactions at work influence both behavior and attitudes (Fisher, 2002; Brief \& Weiss, 2002). Some specific affective reactions (anger, frustration) have been linked to objective features of the physical work environment (e.g. Ashkanasy et al., 2014; Brown \& Robinson, 2011), but the growing literature on organizational aesthetics suggests that perceiving beauty is an important factor (Proyer, Gander, Wellenzohn \& Ruch, 2016; White, 1996). Previous research has established the role and importance of aesthetic functions within the physical environment (Rafaeli \& Vilnai-Yavetz, 2004).

In our framework of psychological affective reactions to the work environment, we propose the dimension of Sense of Beauty. This dimension involves employees' non-cognitive (emotional) responses to the work environment (Bitner, 1992). When people perceive beauty, they experience positive affect (Proyer et al., 2016). White (1996), in reviewing the relevance of aesthetics to organizations, finds that the experience of beauty is an essential, constitutive element of organizations and has important implications in organization theory; it is universal and necessary. The design of a physical work environment to elicit a sense of beauty can produce positive feelings, behaviors and cognitions (Sin \& Lyubomirsky, 2009). The appreciation of beauty has been demonstrated to increase well-being (Proyer et al., 2016). Research has also shown that the degree to which the physical work environment has a pleasing and attractive appearance shapes trust formation in organizations (Baer, van der Werff, Colquitt, Rodell, Zipay, \& Buckley, 2017). An aesthetically pleasing environment that evokes a sense of beauty may provide an experience that is restorative (Nasar, 1997). Researchers have suggested that preference for beautiful environments may play a role in attracting people to restorative environments and keeping them for a longer time than would otherwise be the case, allowing them to recover from attentional fatigue and stress (Hartig, Böök, Garvill, Olsson, \& Gärling, 1996; Hull \& Michael, 1995; Kaplan, 
1995). As such, we propose that sense of beauty is an essential and previously neglected aspect of employee affective reactions to the physical work environment.

3.3 Relational Reactions. Relational factors in psychological theory examine the role of interpersonal interactions and interdependencies at work (Grant \& Parker, 2009). Relatedness is one of three basic needs in self-determination theory that lead to enhanced motivation and mental health (Ryan \& Deci, 2000). Moreover, success in modern workplaces is often driven by how well individuals interact with each other and with the organization (Elsbach \& Flynn, 2013). For example, project-based teams are frequently used in organizations and tasked with solving multi-disciplinary problems requiring them to work interdependently with a range of different stakeholders to achieve outcomes (Cross, Rebele \& Grant, 2016). Consistent with the increasingly interdependent nature of work, work designs requiring employees to work together to achieve goals have increased by $50 \%$ in the past two decades (Cross et al., 2016). The physical work environment significantly influences with whom and how often one interacts (e.g. Cohen, 2007; Elsbach \& Pratt, 2007; Khazanchi, Sprinkle, Masterton \& Tong, 2018; Millward, Haslam, \& Postmes, 2007; Oldham et al., 1995; Wineman, Hwang, Kabo, Owen-Smith \& Davis, 2014 ), and as such plays a vital role in supporting or detracting from interdependent work. When the design of the physical work environment facilitates a sense of belonging, individuals are likely to feel connected to a larger whole beyond themselves. For example, a key factor in the success of the coworking space provider WeWork has been building a strong sense of community, largely through the design of the physical work environment (Turk, 2018).

The final factor in the proposed framework is Connectedness, which incorporates the relational aspects of psychological reactions. The experience of connection involves the extent to which the environment facilitates a sense of 
community and a feeling of belonging to the organization (Morrow et al., 2012; Vischer, 2008). Connectedness is an important reaction that the physical work environment may inhibit or enhance. The more the work environment fosters encounters, conversations, and engagement with others, the more employees feel that they are part of the larger social group, that they know others, and that they are jointly part of a greater whole, supporting the innate need of human beings to belong (Leary \& Baumeister, 2017). A physical work environment that facilitates more frequent and higher quality contact with others leads to improved communication and task-related assistance (Alderfer \& Smith, 1982; Tuckman, 1965), increased job satisfaction (Ryan \& Deci, 2001), and more social support (Andrade \& Devlin, 2015). As such, a sense of connectedness is likely to be an important precursor to many other outcomes, including collaboration, cohesion, and even self-worth, which in turn influence organizational outcomes such as performance, citizenship, retention, commitment, and creativity (Grant \& Parker, 2009).

Guided by our three-dimensional theoretical framework of employee reactions to the work environment (Focus, Sense of Beauty and Connectedness), we conducted four studies to develop and test a measure of these reactions for use in future research. Study 1 involved pilot tests with three different samples to develop and refine a pool of items. In Study 2, an initial survey was developed to assess the dimensional structure of the measure and to enable preliminary convergent validity testing. Study 3 further confirmed the dimensional structure of the measure and tested its predictive validity for work outcomes. Finally, the fourth study introduced a longitudinal component in a quasi-experimental design, using a sample of employees who changed physical work locations between pre and post-tests. The results of Study 4 demonstrated that the 
measure reflects reactions to one's specific environment, rather than stable individual differences between employees.

\section{Study 1: Scale Development}

\subsection{Delphi Interviews}

We began our scale development with semi-structured Delphi interviews (Linstone \& Turoff, 1975) of six workplace designers who assisted companies with the creation, implementation, and management of their physical work environments. We used a Delphi interview process to gain knowledge from experts because theoretical consensus was lacking (Dalkey \& Helmer, 1963; Linstone \& Turoff, 1975). The designers' work experience and expertise gave them unique insights into how employees respond to work environments. The interviewees had between 9 and 40 years of experience working with firms in different industries around the world, including leading global organizations such as the BBC, Apple, the British Library, Barclays, and Boeing.

We asked interviewees to describe the most important features of the physical work environment, discuss which employee needs and responses they felt were most important, give examples of work environment aspects which they had found to create successful outcomes, and suggest key problems related to the design of the physical work environment. Thematic analysis of their responses supported the focus, sense of beauty and connectedness framework proposed above. Initial interpretations were fed back to participants to gain further insight (Dalkey \& Helmer, 1963; Linstone \& Turoff, 1975). For example, the interviewees noted that problematic workplaces tended to be noisy ones where employees were constantly interrupted and had no place to escape distractions; whereas workplaces that promoted effective work performance offered a choice of areas to work in, including visual and auditory privacy. Interviewees also 
noted that ineffective workplaces often were ugly and unappealingly functional in their design, while more successful workplaces had an intimate, attractive feel. Finally, interviewees commented that unsuccessful workplaces often caused employees to feel isolated from their colleagues and their organizations, while effective workplaces were designed in a way that made it easy for individuals to locate and connect with others and the organization.

\subsection{Initial Item Development}

Based on interviewee comments, existing measures (e.g. Kim \& de Dear, 2013), and a review of the literature supplemented by follow-up discussions with the interviewees, we generated a pool of 31 items to reflect the three reactions to the physical work environment (i.e. focus, sense of beauty, connectedness). These items were sent to a purposive sample of 40 respondents selected for their geographic distribution and diversity of physical work environments. Twenty four individuals responded (60\% response rate). The sample was $61 \%$ male, with a modal age of 35-44 years, and represented a variety of occupations and nations. Participants completed an online survey using the 31 items to report their reactions to the physical environment in which they worked.

Correlation patterns suggested that the proposed three-factor structure was present in the data. However, not all items correlated as expected. Using these results and reference to the literature, we revised and retained 21 items reflecting the three reactions to the physical work environment.

\subsection{Item Refinement}

In the final pilot study, the revised 21 items were administered in two very different organizations: a national scientific research organization and a multinational architecture and design firm. With the support of management in each organization, 
120 employees were invited to complete an online survey about their physical work environment, and to provide qualitative feedback on items that were unclear. Fifty-four employees responded (45\% response rate). The sample was 57\% male and had a modal age of 35-44 years. Using exploratory factor analysis and participant feedback, a final list of 12 items was developed, four for each of the three reactions to the physical work environment. We named the 12-item scale that emerged from these studies as the Reactions to the Physical Work Environment Scale (RPWES).

\section{Study 2: Validity and Reliability Testing}

The aim of the second study was to examine the internal structure and reliability of the new 12-item measure, as well as testing the construct validity of the new measure with other related constructs.

\subsection{Sample}

The business network database LinkedIn was used to invite 500 individuals to complete an online survey. The final sample consisted of 185 respondents (37\% response rate) with a modal age of 35-44 years. More than half (62\%) were male and most respondents had more than 10 years' work experience. Respondents were located in North America, Europe, Asia, and the Asia-Pacific region, representing a wide range of industries. Their physical work environments included traditional private offices, open-plan offices, activity-based working spaces, manufacturing facilities, coworking spaces, serviced offices, home offices, and outdoor work.

\subsection{Measures}

Construct validity testing was conducted to confirm that the RPWES could be differentiated from existing and related constructs. Psychological Empowerment is a motivational construct manifested in four cognitions about one’s work (Spreitzer, 1995): meaning (value or purpose perceived in work), competence (belief in one’s 
ability to perform a task), self-determination (experience of autonomy or choice), and impact (one's ability to influence work outcomes). Such thoughts about work tasks should be related to, but distinct from, reactions to the physical work environment. Similarly, the survey included a measure of current mood to distinguish reactions to the environment from more general feelings.

5.2.1 RPWES. The RPWES consisted of the 12 items from Study 1. Respondents were asked to consider 'the physical environment where you work' and responded using ratings from 1 (strongly disagree) to 5 (strongly agree). All items are presented in Table 1.

5.2.2 Psychological Empowerment. This was measured with Spreitzer’s (1995) 12item measure, assessing all four dimensions. Example items include 'I am confident about my ability to do my job' (competence) and 'I can decide on my own how to go about doing my work’ (self-determination). Participants used a scale ranging from 1 (strongly disagree) to 7 (strongly agree).

5.2.3 Mood. Participants' state affect was measured using the Positive and Negative Affect Scale (Watson, Clark \& Tellegen, 1988). The scale contains 20 items, with 10 assessing positive affect (e.g. 'excited') and 10 assessing negative affect (e.g. 'scared'). Participants rated each item with regard to 'how you feel right now' on a scale from 1 (very slightly or not at all) to 5 (extremely).

5.2.4 Importance of Work Environment. To assess whether respondents were influenced by individual differences in their attentiveness to the physical environment, the survey included a three-item measure of the importance of the environment ('My physical work environment is important to me’, 'My physical work environment affects how I work', and 'Where I work is important to me'). Respondents used a scale ranging from 1 (strongly disagree) to 5 (strongly agree). This measure was developed by the authors. 


\subsection{Results and Discussion}

Using the RPWES items, the Kaiser-Meyer-Olkin sampling adequacy test statistic for the items of our scale was .90 (above the threshold of .60; Kaiser, 1974) and Bartlett's (1950) test of sphericity was significant (1713.48, df 66, $p<.01$ ), indicating that factor analysis was appropriate to test the structure of the scale. An exploratory factor analysis using maximum likelihood extraction found a clear three-factor solution that explained 83.0\% of the variance (see Table 1). The factors in the RPWES are moderately correlated with each other. Descriptive statistics for the three factors of the RPWES and all other measures collected in this study are given in Table 2.

All measures had good internal consistency and the pattern of correlations supported the construct validity of the new measure. All aspects of psychological empowerment were significantly correlated with all dimensions of the RPWES (from $r$ $=.21$ to $\mathrm{r}=.45, p<.05$ ), as expected, indicating that the new measure has appropriate convergent validity with related constructs. At the same time, the fact that the correlations were small to moderate indicates discriminant validity. The RPWES was related to, but also clearly distinguishable from, empowerment.

Likewise, the correlations among the RPWES dimensions and mood were as predicted. In other words, it appears that when completing the RPWES, respondents reported distinct reactions to their environment, rather than simply their mood at the time. In addition, all three dimensions of the RPWES had non-significant correlations with the importance of environment measure, suggesting that one's reactions are not directly influenced by how concerned one is with the physical environment.

Taken together, these results indicate that the RPWES three-factor framework of Focus, Sense of Beauty, and Connectedness offers a potentially useful and generalizable way to assess individual reactions to the physical work environment. In a 
sample of culturally and occupationally diverse working adults, the RPWES had a strong factor structure, good internal reliability and appropriate relationships with related constructs.

Table 1. Study 2 Exploratory Factor Analysis Reactions to Physical Work Environment Scale (RPWES).

\begin{tabular}{|c|c|c|c|}
\hline Item & $\begin{array}{c}\text { Factor } 1 \\
\text { Focus } \\
\end{array}$ & $\begin{array}{c}\text { Factor } 2 \\
\text { Beauty }\end{array}$ & $\begin{array}{l}\text { Factor } 3 \\
\text { Connection }\end{array}$ \\
\hline \multicolumn{4}{|l|}{ Focus } \\
\hline $\begin{array}{l}\text { Allows me to concentrate when I } \\
\text { need to }\end{array}$ & .81 & .37 & .12 \\
\hline $\begin{array}{l}\text { Allows me to control distractions to } \\
\text { my work }\end{array}$ & .88 & .15 & .10 \\
\hline $\begin{array}{l}\text { Makes it easy for me to focus on my } \\
\text { work }\end{array}$ & .91 & .25 & .10 \\
\hline Helps to concentrate my attention & .85 & .29 & .11 \\
\hline \multicolumn{4}{|l|}{ Sense of beauty } \\
\hline Is beautiful & .28 & .82 & .26 \\
\hline Is attractive & .35 & .80 & .35 \\
\hline Is stylish & .33 & .81 & .27 \\
\hline Is visually pleasing & .30 & .79 & .38 \\
\hline \multicolumn{4}{|l|}{ Connectedness } \\
\hline $\begin{array}{l}\text { Allows me to feel a sense of } \\
\text { belonging to the organisation }\end{array}$ & .24 & .24 & .70 \\
\hline Allows me to feel connected & .08 & .29 & .65 \\
\hline $\begin{array}{l}\text { Allows me to feel part of the } \\
\text { organisation }\end{array}$ & .04 & .13 & .90 \\
\hline $\begin{array}{l}\text { Allows me to see myself as a member } \\
\text { of a community to which I belong }\end{array}$ & .04 & .22 & .67 \\
\hline Eigenvalue & 6.67 & 2.21 & 1.07 \\
\hline $\begin{array}{l}\text { Cumulative percentage of variance } \\
\text { explained }\end{array}$ & 55.63 & 74.07 & 83.00 \\
\hline
\end{tabular}

$\mathrm{n}=128$; maximum likelihood extraction with orthogonal rotation. Primary factor loading in bold. 
Table 2. Study 2 Means, Standard Deviations, Correlations, and Reliability

\begin{tabular}{|c|c|c|c|c|c|c|c|c|c|c|c|c|c|}
\hline & Variable & Mean & $S D$ & $\alpha$ & 1 & 2 & 3 & 4 & 5 & 6 & 7 & 8 & 9 \\
\hline 1 & Focus & 3.43 & 1.07 & .95 & & & & & & & & & \\
\hline 2 & Sense of beauty & 3.18 & 1.12 & .96 & $.60 * *$ & & & & & & & & \\
\hline 3 & Connectedness & 3.45 & .89 & .86 & $.30 * *$ & $.57 * *$ & & & & & & & \\
\hline 4 & Psychological empowerment: & & & & & & & & & & & & \\
\hline & Meaning & 6.15 & 1.01 & .93 & $.30 * *$ & $.36 * *$ & $.41^{* *}$ & & & & & & \\
\hline 5 & Psychological empowerment: & & & & & & & & & & & & \\
\hline & Competence & 6.18 & .71 & .86 & $.27 * *$ & $.24 * *$ & $.21 *$ & $.44^{* *}$ & & & & & \\
\hline 6 & $\begin{array}{l}\text { Psychological empowerment: Self- } \\
\text { determination }\end{array}$ & 6.33 & .83 & .89 & $.38 * *$ & $.43 * *$ & $.31 * *$ & $.43 * *$ & $.49 * *$ & & & & \\
\hline 7 & Psychological empowerment: Impact & 5.78 & 1.49 & .95 & $.41^{* *}$ & $.45 * *$ & $.22 *$ & $.33 * *$ & $.24 * *$ & $.52 * *$ & & & \\
\hline 8 & Positive affect & 3.75 & .67 & .91 & $.41^{* *}$ & $.43 * *$ & $.42 * *$ & $.63 * *$ & $.43 * *$ & $.46^{* *}$ & $.35 * *$ & & \\
\hline 9 & Negative affect & 1.52 & .50 & .86 & $-.34 * *$ & $-.28 *$ & $-.18^{*}$ & $-.19 *$ & $-.41 * *$ & $-.32 * *$ & -.04 & $-.36 * *$ & \\
\hline 10 & Importance of environment & 4.30 & .68 & .79 & .07 & -.02 & -.11 & .09 & .12 & -.11 & .03 & .04 & -.01 \\
\hline
\end{tabular}
$\mathrm{n}=128$

$* \mathrm{p} \leqq .05 ; * * \mathrm{p} \leqq .01$ 


\section{Study 3: Predictive Validity}

The aim of Study 3 was to begin to test the predictive validity of the RPWES. The outcome measures used in this study were Organizational Citizenship Behavior and Collaboration. Organizational Citizenship Behavior (OCB) involves actions that go beyond the requirements of one's formal employment role and contribute to performance (Organ, 1990). OCB comprises actions that contribute to the maintenance of the organization's social system and have been described as behavioral manifestations of positive cooperation at work (LePine, Erez \& Johnson, 2002). Examples of OCBs include helping others with their tasks, putting in extra effort at work, and promoting the organization. OCBs have been shown to predict a range of important outcomes inluding managerial ratings of employee performance, productivity, efficiency, customer satisfaction and turnover (Podsakoff, Whiting, Podsakoff \& Blume, 2009).

Previous findings (Turnipseed \& Murkison, 2000) suggested that connectedness, but not focus or sense of beauty, would predict OCB. Individuals are more likely to be cooperative and helpful when they feel a connection to the organization and the individuals in it, while there is no reason to believe that focus or sense of beauty would directly influence OCB.

The second variable we examined was collaboration. Collaboration refers to joint activity with one or more co-workers to accomplish goals. This is another important behavior in organizations (Bedwell et al., 2012). Consistent with the increasingly interdependent nature of work, collaborative endeavors have increased by $50 \%$ in the past two decades (Cross et al., 2016), in part because collaboration contributes to competitive advantage (Bedwell et al., 2012), creativity (Elsbach \& Flynn, 2013), and success in complex tasks (Bruns, 2013). Previous studies 
(Heerwagen et al., 2004; Morrow et al., 2012) suggested that the work environment may influence collaboration by facilitating interaction and by enhancing the ability of workers to focus on tasks. As such, we predict that connectedness and focus, but not sense of beauty, should predict collaboration.

\subsection{Sample and Procedure}

Employees in one European office of a multinational organization were invited to complete an online survey. Two hundred and eleven of 290 employees completed the survey (response rate 77\%). The mean age of the respondents was 31.8 years (SD 12.1), and two-thirds (66\%) were male.

\subsection{Measures}

All respondents completed the RPWES and self-report measures of the two outcomes. The survey also included the three-item measure of the importance of the environment from Study 2 as a marker variable to assess common method bias (Lindell \& Whitney, 2001).

6.2.1 RPWES. Respondents completed the RPWES from Study 2 (as described in Section 5.2.1).

6.2.2 OCB. Respondents completed Wayne, Shore and Lidens' (1997) seven-item scale of Citizenship Behaviors (e.g. 'I help others with their work when they have been absent even if it is not my job to do so'), with anchors from 1 (never) to 7 (always).

6.2.3 Collaboration. To measure collaboration, respondents completed Pinto and Pinto’s (1990) six-item scale (e.g. 'It is easy to brainstorm about ideas'), with anchors from 1 (never) to 6 (always).

6.2.4. Environmental Importance. Finally, respondents completed the Importance of the Work Environment scale described in Study 2 (Section 5.2.4). 


\subsection{Results and Discussion}

Summary statistics for all scales are given in Table 3. All measures had good reliability, and the predicted relationships emerged. In particular, consistent with Study 2 (Section 5), the importance of the work environment measure was not related to employee reactions to the work environment. This result is important in two regards. First, it corroborates the Study 2 finding that the three dimensions of reactions to the work environment are independent of the importance an individual places on their work environment. Second, it suggests that common method variance is unlikely to be a significant concern in these data (Podsakoff, MacKenzie, Lee, \& Podsakoff, 2003).

Table 3. Study 3 Means Standard Deviations, Correlations and Reliability

\begin{tabular}{|c|c|c|c|c|c|c|c|c|}
\hline Variable & Mean & $S D$ & $\alpha$ & 1 & 2 & 3 & 4 & 5 \\
\hline 1 Focus & 3.73 & 1.55 & .96 & & & & & \\
\hline 2 Sense of beauty & 4.03 & 1.58 & .94 & $.58 * *$ & & & & \\
\hline 3 Connectedness & 5.07 & 1.11 & .90 & $.47 * *$ & $.57 * *$ & & & \\
\hline 4 Collaboration & 4.82 & 1.13 & .91 & $.51 * *$ & $.51 * *$ & $.60 * *$ & & \\
\hline $\begin{array}{l}\text { citizenship behavior } \\
6 \text { Importance of }\end{array}$ & 4.61 & 1.12 & .88 & $.24 * *$ & $.17^{*}$ & $.33^{* *}$ & $.31^{* *}$ & \\
\hline environment & 6.24 & .75 & .79 & .00 & -.01 & .09 & -.01 & $.19 * *$ \\
\hline
\end{tabular}

To assess the performance of the RPWES, three steps were undertaken in the analysis. First, a maximum likelihood estimation confirmatory factor analysis (CFA) of the 12-item RPWES was conducted. The predicted three-factor model fit the data well $\left(\chi^{2}=81.98, \mathrm{df}=51, \mathrm{SRMR}=.04, \mathrm{RMSEA}=.05, \mathrm{CFI}=.99 ; \mathrm{Hu} \&\right.$ Bentler, 1999). It also had a significantly better fit than any of the alternative models that combined two of the three factors into one (see Table 4). These results confirm that the scale has three distinct factors. 
Table 4. Confirmatory Factor Analysis for RPWES

\begin{tabular}{|c|c|c|c|c|c|c|c|}
\hline & Model & $\chi^{2}$ & $d f$ & $\Delta \chi^{2}$ & SRMR & RMSEA & CFI \\
\hline 1 & Three-factor scale: Focus, Sense of Beauty and Connectedness & 81.98 & 51 & & .04 & .05 & .99 \\
\hline 2 & Two-factor scale: Model 1 except combining Focus + Sense of Beauty as one factor & 652.57 & 53 & $570.59 * a$ & .12 & .23 & .75 \\
\hline 3 & $\begin{array}{l}\text { Two-factor scale: Model } 1 \text { except combining Sense of Beauty + Connectedness as } \\
\text { one factor }\end{array}$ & 410.37 & 53 & $328.39 * a$ & .12 & .18 & .85 \\
\hline 4 & Two-factor scale: Model 1 except combining Focus + Connectedness as one factor & 474.00 & 53 & $392.02 * \mathrm{a}$ & .15 & .19 & .83 \\
\hline 5 & Five-factor model: Focus, Sense of Beauty, Connectedness, Collaboration and OCB & 419.56 & 265 & & .05 & .05 & .96 \\
\hline 6 & $\begin{array}{l}\text { Four-factor model: Model 5, except combining OCB + Sense of Beauty as one } \\
\text { factor }\end{array}$ & 1070.02 & 269 & $650.46^{* b}$ & .15 & .12 & .80 \\
\hline 7 & Four-factor model: Model 5, except combining OCB + Connectedness as one factor & 883.35 & 269 & $463.79 * \mathrm{~b}$ & .13 & .10 & .85 \\
\hline 8 & Four-factor model: Model 5, except combining OCB + Focus as one factor & 1256.78 & 269 & $837.22 * \mathrm{~b}$ & .16 & .13 & .76 \\
\hline 9 & $\begin{array}{l}\text { Four-factor model: Model 5, except combining Collaboration }+ \text { Sense of Beauty as } \\
\text { one factor }\end{array}$ & 963.94 & 269 & $544.38 * b$ & .11 & .11 & .83 \\
\hline 10 & $\begin{array}{l}\text { Four-factor model: Model 5, except combining Collaboration + Connectedness as } \\
\text { one factor }\end{array}$ & 668.49 & 269 & $248.93 * b$ & .07 & .08 & .90 \\
\hline 11 & Four-factor model: Model 5, except combining Collaboration + Focus as one factor & 989.03 & 269 & $569.47 * \mathrm{~b}$ & .11 & .11 & .82 \\
\hline 12 & $\begin{array}{l}\text { Structural model: Focus, Sense of Beauty and Connectedness predicting } \\
\text { Collaboration and OCB }\end{array}$ & 420.37 & 266 & & .05 & .05 & .96 \\
\hline
\end{tabular}

$\mathrm{n}=211 ;{ }^{\mathrm{a}}$ compared to model $1 ;{ }^{\mathrm{b}}$ compared to model 5.

${ }^{*} \mathrm{p}<0.01$ 
The second step was a five-factor CFA of the RPWES with OCB and Collaboration. The model fit the data well $\left(\chi^{2}=419.56, \mathrm{df}=265, \mathrm{SRMR}=.05\right.$, RMSEA $=.05$, CFI = .96) and significantly better than any alternative models, which combined OCB with one of the RPWES factors or collaboration with one of the RPWES factors. These results further support the discriminant validity of the RPWES.

The final step was examining a structural model in which the three-factor RPWES predicted collaboration and OCB. The model fit the data well $\left(\chi^{2}=420.37\right.$, df $=266$, SRMR $=.05$, RMSEA $=.05$, CFI $=.96)$ and revealed Focus as a significant predictor of collaboration $(\beta=.11, p=.02)$, but not of OCB $(p=.32)$. In contrast, Sense of Beauty was not consistently related to either collaboration $(p=.06)$ or OCB ( $p=$ $.40)$. Connectedness was a significant predictor of collaboration $(\beta=.46, p<.01)$ and of OCB $(\beta=.41, p<.01)$. The fact that the three reactions to the physical work environment had significant relationships with these important outcomes suggests the importance of those reactions, and the fact that each reaction had a different set of relationships with the outcomes gives further evidence of their discriminant validity and predictive utility.

\section{Study 4: Replication and Extension of Predictive Validity Findings}

The aim of Study 4 was to examine the validity and utility of the RPWES following a change of physical work environment.

\subsection{Sample and procedure}

Ten months after Study 3, the 211 respondents from Study 3 were invited to complete a second survey. Six weeks before this second survey invitation, all respondents moved from several different previous locations into a newly constructed office. A new survey was conducted asking them to report on their psychological reactions to the new physical work environment. Seventy-four respondents completed the second survey 
(response rate 35\%). The mean age of the respondents was 34.7 years (SD 6.7) and 61\% were male. The respondents were matched between the first and second surveys using a unique numerical identifier.

To replicate and extend the findings in Study 3 (Section 6.3), the same measures were used in this study with the same individuals in the same jobs and work teams. The only change between surveys was their recent move to a new work location. Therefore, we contend that any observed changes should primarily reflect the change in their environment.

\subsection{Measures}

The survey included the RPWES and collaboration measures from Study 3 (Sections 6.2.1 and 6.2.3) measured on Likert scales ranging from strongly disagree (1) to strongly agree (7).

\subsection{Results and Discussion}

Table 5 provides descriptive statistics for the study variables in the sample at both time points. All measures had good reliability and there was clear evidence that individuals had different reactions to the two environments. Analysis of variance found that, on average, focus reactions significantly increased at the new location ( $\mathrm{M}$

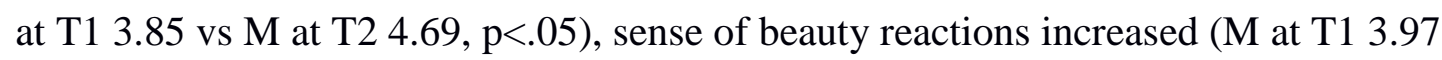
vs $\mathrm{M}$ at T2 5.91, $\mathrm{p}<.05$ ), while connectedness reactions did not change significantly. (M at T1 5.26 vs $\mathrm{M}$ at T2 5.39, $\mathrm{p}<.05$ ).

Individual change scores for all variables were constructed and used in an ordinary least squares regression to test whether the change in each individual's reactions predicted his or her change in collaboration (Table 6). Consistent with Study 3 , both the change in focus $(\beta=.21, p=.08)$ and the change in connectedness ( $\beta=.23, p=.12$ ) were positively associated with the change in collaboration, while the 
change in sense of beauty was not $(\beta=.00, p=n s)$. The pattern of relationships thus replicated the previous findings, but in this case they were change scores reflecting the effects of the new environment. That is, as expected, change in individuals' collaboration reflected the changes in their focus and connectedness reactions provoked by the new office environment.

Given that two of the three reactions showed significant mean differences with the move to a new location, RPWES responses appear to reflect genuine reactions to the environment, rather than stable individual differences. At the same time, we did not find evidence of change in connectedness reactions. This result could be explained in three ways. First, it is possible that connectedness scores on the RPWES reflect individual differences rather than genuine reactions to the environment. Second, connectedness reactions may be more idiosyncratic than the other two reactions. Since ANOVA compares mean scores, if half of the group felt that the new space promoted connection more and the other half felt it promoted connection less, the net result would no change in the mean (i.e., a non-significant ANOVA test). Finally, it may be that connectedness scores require more time to adjust. One's sense of beauty reaction is likely to be almost immediate, and the focus-related implications of a new environment should be revealed quite quickly. In contrast, it may take time for people to develop work routines in the new space and to understand those routines' implications for connection. Our data cannot distinguish between these three possible explanations, so further investigation is needed. 
Table 5. Study 4 Means, Standard Deviations, Correlations, and Reliability

\begin{tabular}{llcccccccccc}
\hline & Variable & Mean & SD & $\alpha$ & 1 & 2 & 3 & 4 & 5 & 6 & 7 \\
\hline 1 & Focus Time 1 & 3.85 & 1.59 & .95 & & & & & & & \\
2 & Focus Time 2 & 4.69 & 1.64 & .96 & $.34^{* *}$ & & & & & \\
3 & Sense of Beauty Time 1 & 3.97 & 1.53 & .96 & $.53^{* *}$ & .17 & & & & & \\
4 & Sense of Beauty Time 2 & 5.91 & 1.09 & .93 & .16 & $.46^{* *}$ & -.15 & & & & \\
5 & Connectedness Time 1 & 5.26 & .99 & .90 & $.51^{* *}$ & .16 & $.55^{* *}$ & .06 & & & \\
6 & Connectedness Time 2 & 5.39 & 1.15 & .92 & .10 & $.55^{* *}$ & $.03^{*}$ & $.55^{* *}$ & $.23^{*}$ & & \\
7 & Collaboration Time 1 & 4.92 & 1.11 & .90 & $.49^{* *}$ & .18 & $.44^{* *}$ & .09 & $.58^{* *}$ & $.24^{*}$ & \\
8 & Collaboration Time 2 & 5.10 & 1.02 & .91 & .20 & $.50^{* *}$ & $.26^{*}$ & $.35^{* *}$ & $.26^{*}$ & $.54^{* *}$ & $.40^{* *}$ \\
\hline
\end{tabular}

$\mathrm{n}=74$

$* \mathrm{p} \leqq .05 ; * * \mathrm{p} \leqq .01$

Table 6. Summary of regression model

\begin{tabular}{lc}
\hline & $\begin{array}{c}\text { Dependent Variable: } \\
\text { Change in Collaboration }\end{array}$ \\
\hline Constant & $-.05(.18)$ \\
Change in Focus & $.21(.08)^{* *}$ \\
Change in Sense of Beauty & $.00(.07)$ \\
Change in Connectedness & $.23(.12)^{*}$ \\
$F$ & $8.96(3,70)^{* *}$ \\
$\mathrm{R}^{2}$ & .28 \\
\hline $\mathrm{n}=74 ;$ standard errors in parentheses \\
$* \mathrm{p} \leqq .05 ;{ }^{* *} \mathrm{p} \leqq .01$
\end{tabular}




\section{General Discussion}

There is no question that physical work environments can have powerful effects on individual behavior (Knight \& Baer, 2014), but the mechanisms of such effects are not clearly established. In response to calls for progress in this regard (Davis et al., 2011; Elsbach \& Pratt, 2007), we have developed a theoretical framework reflecting three dimensions of psychological reactions to work environments (Bandura, 1999; Mischel \& Shoda, 2008). We argue that these three reactions are likely to mediate the relationship between objective characteristics of the physical work environment and subsequent employee behavior.

Across four studies, diverse samples of working adults were used to refine a framework and associated measure: the Reactions to the Physical Work Environment Scale (RPWES). The measure performed well among respondents from multiple industries, continents, occupations, hierarchical levels, and work settings. It showed good psychometric properties and appropriate relationships with other constructs. The results suggest that the three-factor structure of reactions is an appropriate and useful one. The three reactions were shown to be distinct from perceptions of psychological empowerment, positive and negative mood, and the level of attention paid to the physical work environment. Moreover, the work environment reactions were related to important outcomes, including organizational citizenship behavior and collaboration.

The three dimensional framework and associated RPWES provide the foundation for developing an integrated and unifying theory of how physical work environments influence organizational behavior and outcomes. Although many studies have examined the effects of specific environmental features such as noise or greenery, they have usually done so in atheoretical ways and failed to consider how the environment is perceived and why it subsequently influences behavior (Davis et al., 
2011). The RPWES and its framework can address this issue by providing a reliable and widely applicable means of assessing employees’ reactions to their physical work environment as a whole, or by isolating and manipulating specific objective characteristics such as density or natural light. By focusing on the important role of individual reactions and doing so with a consistent framework, future researchers can compare findings, identify similarities and differences, assess the impact of different environmental features, and thereby accumulate a body of knowledge which will be useful to organizations and designers.

\section{Practical Significance}

Several implications for practice are apparent. Our studies have shown that individuals may view similar work environments differently. As such, the need to design work environments that provide options to cater to individual preferences is clear. As studies of open plan work environments have demonstrated (Kim \& de Dear, 2013), there is a need for workplaces that allow for individual choices, as well as differences in the types of work undertaken within organizations. The identification of the three reactions of the RPWES will assist designers of physical work environments to plan and deliver workspaces that optimize all three reactions. Presently, many workplaces are heavily focussed on driving collaboration and interaction (Heerwagen et al., 2004) at the expense of privacy and concentration. The RPWES framework highlights the importance of providing environments that support all three psychological reactions.

\section{Limitations}

A limitation in our studies is the restricted sample we used (i.e. knowledge workers) on the generalizability of the scale. We specifically scoped our data collection around knowledge workers, and so further research is needed to generalize our findings to other contexts. 
Another limitation emerges from our methodology in which all our data are based on self-report and largely cross sectional data. Future research might assess the relationship between employee reactions to the work environment and objective measures such as absenteeism, sick leave, and turnover across different environments.

\section{Future Directions}

The RPWES establishes a framework for describing reactions to the physical work environment. Reactions provide the link between concrete features of the environment and employee behavior; they can explain how features such as equipment, color scheme and office layout may influence behavior and performance.

In terms of the antecedents of focus, research has shown that workplace environments vary in their ability to support attention, based in part on how much distraction is present and how much support the space provides for individuals to adjust the level of distraction they experience (Lee \& Brand, 2005; Veitch \& Gifford, 1996). For example, noisy workplaces disrupt cognitive processing, leading to significant deteriorations in concentration (Banbury \& Berry, 2005). As such, investigating how levels of privacy, distraction, and environmental control in the physical work environment influence focus is an important next step that will have important implications for the design of workplaces.

With respect to the experience of a sense of beauty, scholars have shown that aspects of the physical work environment such as use of natural materials, particular colors, views, lighting, and plant life can create more positive appraisals of aesthetic surroundings (e.g., Ceylan, Dul \& Aytac, 2008; Larsen, Adams, Deal, Kweon \& Tyler, 1998). Indeed, given that the aesthetic experience of beauty is a universal human response (Wilson, 1984), it is worth investigating which factors contribute to sense of beauty in work places. 
With regard to antecedents of connectedness, others have noted that a sense of territory and control within the physical work environment is associated with a sense of belonging or connection (Brown, Lawrence \& Robinson, 2005; Vischer, 2008). Given that many employees now have much smaller spaces and less control over them (Davis et al., 2011), the effect of modern trends in efficient office design such as activity-based working require further investigation as to how they may support or detract from a sense of connectedness. Density, spatial layout, furniture placement, and design may all have implications for a sense of connectedness.

\section{Conclusion}

Billions of dollars are spent annually on building workplace environments. This research may support managers and organizations in making decisions about the type of environments most likely to support their goals. By understanding how employees react to the physical work environment, managers will be better able to address the cognitive, affective, and relational needs of employees.

\section{Acknowledgments}

The authors gratefully acknowledge the support of Clare Morrison in copy-editing this paper for submission.

\section{Funding Sources}

This research did not receive any specific grant from funding agencies in the public, commercial, or not-for-profit sectors. 


\section{References}

Alderfer, C. P. \& Smith, K. K. (1982). Studying intergroup relations embedded in organizations. Administrative Science Quarterly, 27, 35-65.

Alter, A. (2013). Drunk Tank Pink: And Other Unexpected Forces That Shape How We Think, Feel, and Behave. London: Penguin.

Alvesson, M. (2001). Knowledge work: Ambiguity, image and identity. Human Relations, 54(7), 863-86.

Andrade, C. C., \& Devlin, A. S. (2015). Stress reduction in the hospital room: Applying Ulrich's theory of supportive design. Journal of Environmental Psychology,41, $125-34$.

Aries, M. B. C., Veitch, J. A. \& Newsham, G. R. (2010). Windows, view, and office characteristics predict physical and psychological discomfort. Journal of Environmental Psychology, 30, 533-41.

Ashkanasy, N. M., Ayoko, O. B. \& Jehn, K. A. (2014). Understanding the physical environment of work and employee behavior: an affective events perspective. Journal of Organizational Behavior, 35, 1169-84.

Baer, M., van der Werff, L., Colquitt, J. A., Rodell, J. B., Zipay, K., \& Buckley, F. (2017). Trusting the" Look and Feel": Situational Normality, Situational Aesthetics, and the Perceived Trustworthiness of Organizations. Academy of Management Journal, doi/abs/10.5465/amj.2016.0248.

Bakker, A. B., \& Demerouti, E. (2007). The job demands-resources model: State of the art. Journal of Managerial Psychology, 22(3), 309-28.

Bakker, A. B., \& Demerouti, E. (2017). Job demands-resources theory: Taking stock and looking forward. Journal of Occupational Health Psychology, 22(3), 273-85. 
Baldry, C. and Hallier, J. (2009). Welcome to the house of fun: Work space and social identity. Economic and Industrial Democracy, 31, 150-72.

Banbury, S. P. \& Berry, D. C. (2005). Office noise and employee concentration: identifying causes of disruption and potential improvements. Ergonomics, 48, 25-37.

Bandura, A. (1999). A social cognitive theory of personality. In Pervin, L. and John, O. (Eds.), Handbook of Personality. New York: Guilford Publications, 154-96.

Baron, R. A. (1994). The physical environment of work settings: effects on task performance, interpersonal relations, and job satisfaction. In Staw, B. M. and Cummings, L. L. (Eds.), Research in Organizational Behavior. Greenwich, CT: JAI Press, Vol. 16, 1-46.

Bartlett, M. S. (1950). Tests of significance in factor analysis. British Journal of Statistical Psychology, 3, 77-85.

Bazerman, M. H. \& Chugh, D. (2006). Decisions without blinders. Harvard Business Review, 84, 88-97.

Bedwell, W. L., Wildman, J. L., DiazGranados, D., Salazar, M., Kramer, W. S. \& Salas, E. (2012). Collaboration at work: an integrative multilevel conceptualization. Human Resource Management Review, 22, 128-45.

Bergström, J., Miller, M., \& Horneij, E. (2015). Work environment perceptions following relocation to open-plan offices: A twelve-month longitudinal study. Work, 50(2), 221-8.

Bitner, M. J. (1992). Servicescapes: the impact of physical surroundings on customers and employees. Journal of Marketing, 56, 37-50.

Brief, A. P. \& Weiss, H. M. (2002). Organizational behavior: Affect in the workplace. Annual Review of Psychology, 53, 279-307. 
Brown, G., Lawrence, T. B. \& Robinson, S. L. (2005). Territoriality in organizations. Academy of Management Review, 30, 577-94.

Brown, G. \& Robinson, S. L. (2011). Reactions to territorial infringement. Organization Science, 22, 210-24.

Bruns, H. C. (2013). Working alone together: Coordination in collaboration across domains of expertise. Academy of Management Journal, 56(1), 62-83.

Caza, B. B., Tiedens, L. \& Lee, F. (2011). Power becomes you: the effects of implicit and explicit power on the self. Organizational Behavior and Human Decision Processes, 114, 15-24

Ceylan, C., Dul, J. \& Aytac, S. (2008). Can the office environment stimulate a manager's creativity?. Human Factors and Ergonomics in Manufacturing \& Service Industries, 18, 589-602.

Cohen, L. M. (2007). Bridging two streams of office design research: A comparison of design/behavior and management journal articles from 1980-2001. Journal of Architectural and Planning Research, 24, 289-307.

Cross, R., Rebele, R. \& Grant, A. (2016). Collaborative overload. Harvard Business Review, 94, 74-9.

Dalkey, N., \& Helmer, O. (1963). An experimental application of the Delphi method to the use of experts. Management science, 9(3), 458-467.

Dane, E. (2011). Paying attention to mindfulness and its effects on task performance in the workplace. Journal of Management, 37, 997-1018.

Dane, E. (2013). Things seen and unseen: Investigating experience-based qualities of attention in a dynamic work setting. Organization Studies, 34, 45-78.

Davis, T. R. (1984). The influence of the physical environment in offices. Academy of Management Review, 9, 271-83. 
Davis, M. C., Leach, D. J. \& Clegg, C. W. (2011). The physical environment of the office: contemporary and emerging issues. In Hodgkinson, G. P. and Ford, J. K. (Eds), International Review of Industrial and Organizational Psychology. Chichester, UK: Wiley, 193-235.

Elfenbein, H. A. (2007). Emotion in organizations: A review and theoretical integration. The Academy of Management Annals, 1, 315-86.

Elsbach, K. D., \& Flynn, F. J. (2013). Creative collaboration and the self-concept: A study of toy designers. Journal of Management Studies, 50, 515-44.

Elsbach, K. D. \& Pratt, M. G. (2007). The physical environment in organizations. The Academy of Management Annals, 1, 181-224.

Ferro, S. (2015) Six major design trends shaping city life in 2015. Retrieved from http://www.fastcodesign.com/3040823/6-major-design-trends-shaping-city-lifein-2015

Fisher, C. D. (2002). Antecedents and consequences of real-time affective reactions at work. Motivation and Emotion, 26(1), 3-30.

Fried, Y., \& Ferris, G. R. (1987). The validity of the job characteristics model: A review and meta-analysis. Personnel Psychology, 40(2), 287-322.

Gensler. (2013). 2013 U.S. Workplace Survey. Available at: http://www.gensler.com/ uploads/document/337/file/2013_US_Workplace_Survey_07_15_2013.pdf

Goldhill, O. (2013). Google wins final approval for huge British HQ. The Telegraph. Available at: http://www.telegraph.co.uk/finance/newsbysector/constructionand property/10290136/Google-wins-final-approval-for-huge-British-HQ.html

Grant, A. M. (2008). The significance of task significance: Job performance effects, relational mechanisms, and boundary conditions. Journal of Applied Psychology, 93(1), 108-24. 
Grant, A. M., Fried, Y., \& Juillerat, T. (2011). Work matters: Job design in classic and contemporary perspectives. In S. Zedeck (Ed.), APA Handbook of Industrial and Organizational Psychology, Vol. 1. Building and developing the organization (pp. 417-453). Washington, DC, USA: American Psychological Association.

Grant, A. M. \& Parker, S. K. (2009). Redesigning work design theories: the rise of relational and proactive perspectives. The Academy of Management Annals, 3, $317-75$.

Hackman J.R., \& Oldham G.R. (1980). Work Redesign. Reading, MA: AddisonWesley; 1980.

Hartig, T., Böök, A., Garvill, J., Olsson, T., \& Gärling, T. (1996). Environmental influences on psychological restoration. Scandinavian Journal of Psychology, 37(4), 378-93.

Hartog, L., Weijs-Perrée, M., \& Appel-Meulenbroek, R. (2017). The influence of personality on user satisfaction: multi-tenant offices. Building Research \& Information, 46(4), 402-16.

Haynes, B. P. (2008). The impact of office comfort on productivity. Journal of Facilities Management, 6, 37-51.

Hedge, A. (1982). The open-plan office: a systematic investigation of employee reactions to their work environment. Environment and Behavior, 14, 519-42.

Heerwagen, J. H., Kampschroer, K., Powell, K. M., \& Loftness, V. (2004). Collaborative knowledge work environments. Building Research \& Information, 32(6), 510-28.

Herbig, B., Schneider, A., \& Nowak, D. (2016). Does office space occupation matter? The role of the number of persons per enclosed office space, psychosocial work characteristics, and environmental satisfaction in the physical and mental health 
of employees. Indoor Air, 26(5), 755-67.

Hoffman, A. J. \& Ocasio, W. (2001). Not all events are attended equally: toward a middle-range theory of industry attention to external events. Organization Science, 12, 414-34.

Hongisto, V., Varjo, J., Leppämäki, H., Oliva, D., \& Hyönä, J. (2016). Work performance in private office rooms: The effects of sound insulation and sound masking. Building and Environment, 104, 263-74.

Hu, L. \& Bentler, P. M. (1999). Cutoff criteria for fit indexes in covariance structure analysis: conventional criteria versus new alternatives. Structural Equation Modeling, 6, 1-55.

Hull IV, R. B., \& Michael, S. E. (1995). Nature-based Recreation, mood change, and stress restoration. Leisure Sciences, 17(1), 1-14.

Isen, A. M. (1987). Positive affect, cognitive processes, and social behaviour. Advances in Experimental Social Psychology, 20, 203-53.

Isen, A. M., Daubman, K. A., \& Nowicki, G. P. (1987). Positive affect facilitates creative problem solving. Journal of Personality and Social Psychology, 52, 1122.

Kaiser, H. F. (1974). An index of factorial simplicity. Psychometrika, 39, 31-6.

Kaplan, S. (1995). The restorative benefits of nature: Toward an integrative framework. Journal of Environmental Psychology, 15(3), 169-82.

Khazanchi, S., Sprinkle, T., Masterson, S. S., \& Tong, N. (2018). A spational model of work relationships: The relationship-building and relationship-straining effect of workspace. Academy of Management Review. https://doi.org/10.5465/ amr.2016.0240 
Kilduff, G. J., Elfenbein, H. A. \& Staw, B. M. (2010). The psychology of rivalry: A relationally dependent analysis of competition. Academy of Management Journal, 53, 943-69.

Kim, J., Candido, C., Thomas, L., \& de Dear, R. (2016). Desk ownership in the workplace: The effect of non-territorial working on employee workplace satisfaction, perceived productivity and health. Building and Environment, 103, 203-14.

Kim, J., \& de Dear, R. (2012). Nonlinear relationships between individual IEQ factors and overall workspace satisfaction. Building and Environment, 49, 33-40.

Kim, J. \& de Dear, R. (2013). Workspace satisfaction: The privacy-communication trade-off in open-plan offices. Journal of Environmental Psychology, 36, 18-26.

Knight, A. P. \& Baer, M. (2014). Get up, stand up: The effects of a non-sedentary workspace on information elaboration and group performance. Social Psychological and Personality Science, 5, 910-17.

Larsen, L., Adams, J., Deal, B., Kweon, B. S. \& Tyler, E. (1998). Plants in the workplace the effects of plant density on productivity, attitudes, and perceptions. Environment and Behavior, 30, 261-81.

Leaman, A., \& Bordass, B. (1999). Productivity in buildings: the 'killer'variables. Building Research \& Information, 27(1), 4-19.

Leary, M. R., \& Baumeister, R. F. (2017). The need to belong: Desire for interpersonal attachments as a fundamental human motivation. In Interpersonal Development (pp. 57-89). New York: Routledge.

Lee, S. Y. \& Brand, J. L. (2005). Effects of control over office workspace on perceptions of the work environment and work outcomes. Journal of Environmental Psychology, 25, 323-33. 
LePine, J. A., Erez, A. \& Johnson, D. E. (2002). The nature and dimensionality of organizational citizenship behavior: a critical review and meta-analysis. Journal of Applied Psychology, 87, 52.

Liebl, A., Haller, J., Jödicke, B., Baumgartner, H., Schlittmeier, S., \& Hellbrück, J. (2012). Combined effects of acoustic and visual distraction on cognitive performance and well-being. Applied Ergonomics, 43(2), 424-34.

Lindell, M. K. \& Whitney, D. J. (2001). Accounting for Common Method Variance in Cross-Sectional Research Designs.Journal of Applied Psychology, 86(1), 114-21. Linstone, H. A. \& Turoff, M. (Eds). (1975). The Delphi Method: Techniques and Applications. Reading, MA: Addison-Wesley.

Lyubomirsky, S., King, L., \& Diener, E. (2005). The benefits of frequent positive affect: Does happiness lead to success? Psychological Bulletin, 131(6), 803-55.

Marcel, J. J., Barr, P. S. \& Duhaime, I. M. (2011). The influence of executive cognition on competitive dynamics. Strategic Management Journal, 32, 115-38.

McCoy, J. M. (2005). Linking the Physical Work Environment to Creative Context. Journal of Creative Behavior, 39(3), 169-91.

McCoy, J. M. \& Evans, G. W. (2002). The potential role of the physical environment in fostering creativity. Creativity Research Journal, 14, 409-26.

Millward, L. J., Haslam, S. A., \& Postmes, T. (2007). Putting employees in their place: The impact of hot desking on organizational and team identification. Organization Science, 18(4), 547-59.

Mischel, W. \& Shoda, Y. (2008). Toward a unified theory of personality: Integrating dispositions and processing dynamics within the cognitive-affective processing system. In John, O. P., Robins, R. W. and L. A. Pervin (Eds.), Handbook of Personality: Theory and Research (pp. 208-41). New York, NY: Guilford Press. 
Morgeson, F. P., Dierdorff, E. C., \& Hmurovic, J. L. (2010). Work design in situ: Understanding the role of occupational and organizational context. Journal of Organizational Behavior, 31(2 - 3), 351-60.

Morgeson, F. P. \& Humphrey, S. E. (2006). The Work Design Questionnaire (WDQ): developing and validating a comprehensive measure for assessing job design and the nature of work. Journal of Applied Psychology, 91, 1321-29.

Morrow, P. C., McElroy, J. C. \& Scheibe, K. P. (2012). Influencing organizational commitment through office redesign. Journal of Vocational Behavior, 81, 99111.

Nasar J.L. (1997). New Developments in Aesthetics for Urban Design. In Moore G.T., Marans R.W. (eds). Toward the Integration of Theory, Methods, Research, and Utilization. Advances in Environment, Behavior and Design, Vol 4. Springer, Boston, MA

Newsham, G., Brand, J., Donnelly, C., Veitch, J., Aries, M., \& Charles, K. (2009). Linking indoor environment conditions to job satisfaction: a field study. Building Research \& Information, 37(2), 129-147.

Oldham, G. R., Cummings, A. \& Zhou, J. (1995). The spatial configuration of organizations: a review of the literature and some new research directions. Research in Personnel and Human Resource Management, 13, 1-37.

Oldham, G. R., \& Hackman, J. R. (2010). Not what it was and not what it will be: The future of job design research. Journal of Organizational Behavior, 31(2-3), 46379.

Organ, D. W. (1990). The motivational basis of organizational citizenship behavior. Research in Organizational Behavior, 12(1), 43-72. 
Parkinson, A. T., Reid, R., McKerrow, H., \& Wright, D. (2017). Evaluating positivist theories of occupant satisfaction: a statistical analysis. Building Research \& Information, 46(4), 430-443.

Peponis, J., Bafna, S., Bajaj, R., Bromberg, J., Congdon, C., Rashid, M., ... \& Zimring, C. (2007). Designing space to support knowledge work. Environment and Behavior, 39(6), 815-840.

Pejtersen, J. H., Feveile, H., Christensen, K. B., \& Burr, H. (2011). Sickness absence associated with shared and open-plan offices-a national cross sectional questionnaire survey.Scandinavian Journal of Work, Environment \& Health, 37(5), 376-382.

Pinto, M. B. \& Pinto, J. K. (1990). Project team communication and cross-functional cooperation in new program development. Journal of Product Innovation Management, 7, 200-12.

Podsakoff, P. M., MacKenzie, S. B., Lee, J. \& Podsakoff, N. P. (2003). Common method biases in behavioral research: a critical review of the literature and recommended remedies. Journal of Applied Psychology, 88, 879-903.

Podsakoff, N. P., Whiting, S. W., Podsakoff, P. M., \& Blume, B. D. (2009). Individualand organizational-level consequences of organizational citizenship behaviors: A meta-analysis. Journal of Applied Psychology, 94(1), 122-41.

Proyer, R. T., Gander, F., Wellenzohn, S., \& Ruch, W. (2016). Nine beautiful things: A self-administered online positive psychology intervention on the beauty in nature, arts, and behaviors increases happiness and ameliorates depressive symptoms. Personality and Individual Differences, 94, 189-93. 
Rafaeli, A. \& Vilnai-Yavetz, I. (2004). Instrumentality, aesthetics and symbolism of physical artifacts as triggers of emotion. Theoretical Issues in Ergonomics Science, 5, 91-112.

Reinten, J., Braat-Eggen, P. E., Hornikx, M., Kort, H. S., \& Kohlrausch, A. (2017). The indoor sound environment and human task performance: A literature review on the role of room acoustics. Building and Environment, 123, 315-32.

Roethlisberger, F. J., \& Dickson, W. J. (1939). Management and the worker: An account of a research program conducted by the Western Electric Co., Hawthorne Works, Chicago. Cambridge, MA: Harvard University Press.

Ryan, R. M., \& Deci, E. L. (2000). Self-determination theory and the facilitation of intrinsic motivation, social development, and well-being. American Psychologist, 55(1), 68-78.

Ryan, R. M. \& Deci, E. L. (2001). On happiness and human potentials: a review of research on hedonic and eudaimonic well-being. Annual Review of Psychology, 52, 141-66.

Seddigh, A., Berntson, E., Danielson, C. B. \& Westerlund, H. (2014). Concentration requirements modify the effect of office type on indicators of health and performance. Journal of Environmental Psychology, 38, 167-74.

Sin, N. L., \& Lyubomirsky, S. (2009). Enhancing well-being and alleviating depressive symptoms with positive psychology interventions: A practice-friendly metaanalysis. Journal of Clinical Psychology, 65(5), 467-87.

Spinuzzi, C. (2012). Working alone together coworking as emergent collaborative activity. Journal of Business and Technical Communication, 26, 399-441.

Spreitzer, G. M. (1995). Psychological empowerment in the workplace: dimensions, measurement, and validation. Academy of Management Journal, 38, 1442-65. 
Sundstrom, E., Bell, P. A., Busby, P. L. \& Asmus, C. (1996). Environmental Psychology 1989-1994. Annual Review of Psychology, 47, 485-512.

Sundstrom, E. \& Sundstrom, M. G. (1986). Work Places: The Psychology of the Physical Environment in Offices and factories. Cambridge: Cambridge University Press.

Tuckman, B. W. (1965). Developmental sequence in small groups. Psychological Bulletin, 63, 384-99.

Turk, V. (2018). How WeWork became the most hyped startup in the world. Wired. Retrieved from http://www.wired.co.uk/article/we-work-startup-valuationadam-neumann-interview

Turnipseed, D. \& Murkison, G. (2000). Good soldiers and their syndrome: organizational citizenship behavior and the work environment. North American Journal of Psychology, 2, 281-302.

Veitch, J. A. (2018). How and why to assess workplace design: Facilities management supports human resources. Organizational Dynamics, 47, 78-87.

Veitch, J. A. \& Gifford, R. (1996). Choice, perceived control, and performance decrements in the physical environment. Journal of Environmental Psychology, 16, 269-76.

Vischer, J.C. (2008). Towards an environmental psychology of workspace: how people are affected by environments for work. Architectural Science Review, 51, 97108.

Watson, D., Clark, L. A. \& Tellegen, A. (1988). Development and validation of brief measures of positive and negative affect: The PANAS scales. Journal of Personality and Social Psychology, 54, 1063-70. 
Wayne, S. J., Shore, L. M. \& Liden, R. C. (1997). Perceived organizational support and leader-member exchange: a social exchange perspective. Academy of Management Journal, 40, 83-111.

White, D. A. (1996). It's working beautifully! Philosophical reflections on aesthetics and organization theory. Organization, 3(2), 195-208.

Wickens, C.D., Hollands, J.G., 2000. Engineering Psychology and Human Performance, third ed. Prentice-Hall, Upper Saddle River, NJ.

Wilson, E. O. (1984). Biophilia. Cambridge: Harvard University Press.

Wineman, J., Hwang, Y., Kabo, F., Owen-Smith, J., \& Davis, G. F. (2014). Spatial layout, social structure, and innovation in organizations. Environment and Planning B: Planning and Design, 41(6), 1100-1112.

Yanow, D. (1998). Space stories studying museum buildings as organizational spaces while reflecting on interpretive methods and their narration. Journal of Management Inquiry, 7, 215-39.

Zax, D. (2013). Why square designed its new offices to work like a city. Fast Company. Retrieved from http://www.fastcompany.com/3021752/most-creative-people/ why-square-designed-its-new-offices-to-work-like-a-city

Zhong, C. B. \& House, J. (2012). Hawthorne revisited: organizational implications of the physical work environment. Research in Organizational Behavior, 32, 3-22. 